\title{
A Study on the Relationship between Self Directed Learning and Achievement in Information Technology of Students at Secondary Level
}

\author{
Sajna Jaleel ${ }^{*}$, Anuroofa O.M. \\ School of Pedagogical Sciences, Mahatma Gandhi University, India
}

Copyright $\mathrm{C} 2017$ by authors, all rights reserved. Authors agree that this article remains permanently open access under the terms of the Creative Commons Attribution License 4.0 International License

\begin{abstract}
Education at any level has normally been based on some image of the future; that was not impossible in a world that was changing slowly. Today, educators are preparing learners for a world we cannot even predict, and self-directed learning has become an essential foundation for $21^{\text {st }}$ century learners. In recent years teachers are giving importance to technology based education such as student centered education, technology based education, hands-on training, lab-based education and e-learning in the classrooms. The underlying rationale seems to be that students are better able to learn when they can control the flow of their experience, or when their learning is "self-directed." Teachers are also has an important place in Self Directed Learning environment. Their constant support and motivation is required for accelerating the effectiveness and also increasing the rate of achievement. Information Technology (IT) is becoming the subject of $21^{\text {st }}$ century, because knowledge in IT plays a crucial role for the daily living. In this paper, the Investigators tried to find out whether there exists any relationship between Self Directed Learning (SDL) and Achievement in Information Technology of Secondary School Students for the total sample and also for the subsample Gender. The Investigators also tried to find out whether there exists any significant difference in the Self Directed Learning and Achievement in Information Technology of Students at Secondary Level based on Gender. Proper statistical techniques were used for collecting, standardizing and analyzing the data.
\end{abstract}

Keywords Self Directed Learning, IT, Secondary School Students

\section{Introduction}

According to Saxena ${ }^{[1]}$ technology supports all kinds of learning and teaching, and there is nothing today, which cannot be attained or aided by technology. Learning through self-direction can be refined and amplified with the use of technology. Technology can support lifelong, self-directed learning beyond the regular classroom. There has been a great rise in the use of ICT in education, owing to the spread of education among masses across the world, where due to the ready availability of ICT enabled tools, self-directed learning can be enhanced. The context of self-directed learning has now changed with online learning, greater access to technology, personalized learning experiences, and access to information sources that were not available earlier.

Lounsbury et al. ${ }^{[2]}$ defined SDL as a disposition to engage in learning activities where the individual takes personal responsibility for developing and carrying out learning endeavors in an autonomous manner without being prompted or guided by other people (such as a teacher, parent, or peer).

\section{Need and Significance of the Study}

Gibbons ${ }^{[3]}$ claims that SDL is a process that occurs naturally for everyone. Self-directed learning is an essential skill required in the $21^{\text {st }}$ century educational world. This learning approach increases the motivation of students to learn, since they are the makers of their own knowledge, they experience a sense of independence while learning. According to Saxena ${ }^{[1]}$ SDL process keeps them engaged, since now they have to acquire knowledge on their own, and apply it along with their skills to find solutions to their problems that evolve in learning and be encouraged for life-long learning

The 21 st century high school and secondary school students are tends to favor a more independent, autonomous learning style that makes them more assertive information seekers and shapes how they approach learning in the classroom, Carlson ${ }^{[4]}$. In today's fast-paced world, students can access information anywhere and anytime. The attitudes and perceptions of digital learners towards the use of 
computer technology is essential to better understanding the relationship between technology preparedness and self-directed learning. First, it is necessary to define what self-directed learning entails. Knowles ${ }^{[5]}$ defined self-directed learning as a "process in which individuals take the initiative, with or without the help from others, in diagnosing their learning needs, formulating goals, identifying human and material resources, choosing and implementing appropriate learning strategies, and evaluating learning outcomes"

Information Technology is an important subject because today all daily activities are related to technology. Technology plays an important role to run all the activities in an easy going manner. Now we are in an era of knowledge explosion and everywhere we get information. So traditional classroom learning is not enough for gaining the full advantage of the excess information. The only solution that students must try is to process information by using their own knowledge and skill. Here comes the significance and use of Self Directed learning in educational field. Self Directed Learning helps the students to grasp information and it act as a sign for lifelong learning.

\section{Objectives of the Study}

- To find out whether there exist any significant relationship between Self Directed Learning and Achievement in Information Technology of Students at Secondary Level for the Total Sample and Subsample based on Gender

- To find out whether there exist any significant difference between the Self Directed Learning of Students at Secondary Level based on Gender

- To find out whether there exist any significant difference between the Achievement in Information Technology of Students at Secondary Level based on Gender

\section{Hypotheses of the Study}

- There will be significant positive relationship between Self Directed Learning and Achievement in Information Technology of Students at Secondary Level for the Total Sample and Subsample based on Gender

- There will be significant difference in the Self Directed Learning of Students at Secondary Level based on Gender.

- There will be significant difference in the Achievement in Information Technology of Students at Secondary level based on Gender

\section{Methodology}

The Investigators adopted Survey Method for collecting the data using Self Directed Learning Scale and Achievement test in Information Technology. The Investigators administered the tools among Secondary school students. Then the answer sheets were collected, tabulated and suitable statistical techniques were used for analyzing the obtained data.

\section{Sample}

The sample selected for the study consists of 150 secondary school students studying in standard IX from various schools of Ernakulam District. Out of the 150 Secondary School students, 77 were Boys and 73 were Girls. The sample was selected using Stratified Random sampling Technique.

\section{Tools Used for the Study}

- $\quad$ Self Directed Learning Scale: - The investigators prepared and standardized a Self Directed Learning Scale in the form of a Likert type five point scale. This scale is designed to measure self directedness of the learner. The items in this scale are rated on a 5 -point Likert scale (1=strongly disagree and $5=$ strongly agree). This scale has four subscales that are self-motivation, self-management, self-modification and self-monitoring. The initial draft consists of 90 items. After standardization, 30 items having t-value greater than 3.99 were selected for the final draft. The reliability of the Scale was found out by using test - retest method and it was 0.87 . Intrinsic validity was found out as 0.90 and content validity was also established. The maximum score of the scale is 150 .

- Achievement Test in Information Technology: An achievement test in Information Technology was prepared and standardized by the Investigators from selected units of Standard IX Information Technology text book namely 'The way computers work'. The draft test was prepared for 90 marks having multiple choice questions carrying one mark each. Proper weightage was given for content and level of questions. The test was prepared by giving weightage to six domains in the revised Bloom's taxonomy of Educational objectives namely, Remembering, Understanding, Applying, Analysing, Evaluating and Creating. After standardization 30 items having DI between 0.4 and 0.8 and with DP above 0.4 were selected for the final test. The reliability of the test was found to be 0.82 for the whole test using test-retest method. Face validity, Content validity and Intrinsic validity were established for determining the validity of the Test. The Intrinsic validity was found out as 0.97. 


\section{Statistical Techniques Used}

- Descriptive Statistics

- $\quad$ Significance of difference between Means

- Carl Pearson Product moment Correlation

\section{Analysis of Data and Interpretation of Result}

\subsection{Relationship between Self Directed Learning and Achievement in Information Technology of Secondary School Students for the Total Sample and for the Subsample based on Gender}

The Investigators collected the scores of students on Self Directed Learning Scale and Achievement test in Information Technology. The Mean and Standard Deviation obtained for the Total sample and Subsample Boys and Girls on Self Directed Learning and Achievement in Information Technology were given in Table 1.

Table 1 shows that the Mean scores obtained by Girls on variables Achievement in Information Technology and Self Directed Learning are slightly higher than Boys. This implies that Girls have more Self Directed Learning than Boys which leaded to more Achievement for Girls than Boys.

The correlation between Self Directed Learning and Achievement in Information Technology were found out for the Total Sample and the Subsample Gender using Pearson Product moment Correlation. The results obtained are given in Table 2.

Table 2 shows that the correlation coefficients obtained for the Total Sample, Boys and Girls are all positive. This reveals that there exists a significant positive correlation between Achievement in Information Technology and Self Directed Learning for the Total sample and the subsamples Boys and Girls.

\subsection{Comparison of Self Directed Learning and Achievement in Information Technology of Secondary school students based on Subsample Gender}

The Mean and Standard deviation were calculated for the Subsamples Boys and Girls. Significance of difference between the Mean Scores of Boys and Girls were found out for the variables Self Directed Learning and Achievement in Information Technology. The results obtained were given in Table 3.

Table 3 shows there is no significant difference between the Boys and Girls on Achievement in Information Technology and Self Directed Learning of Secondary school students. The Mean scores however show that Girls are slightly higher than Boys in Achievement in Information Technology and Self Directed Learning.

Table 1. Descriptive Statistics for the Total sample and Relevant Subsamples on Achievement in Information Technology and Self Directed Learning

\begin{tabular}{|c|c|c|c|c|c|c|}
\hline \multirow{2}{*}{ Variables } & \multicolumn{2}{|c|}{ Total Sample } & \multicolumn{2}{c|}{ Boys } & \multicolumn{2}{c|}{ Girls } \\
\cline { 2 - 7 } & Mean & S.D & Mean & S.D & Mean & S.D \\
\hline Achievement in Information Technology & 24.07 & 3.50 & 23.73 & 3.26 & 24.44 & 3.71 \\
\hline Self Directed Learning & 130.73 & 5.57 & 130.25 & 5.87 & 131.16 & 5.36 \\
\hline
\end{tabular}

Table 2. Correlation between Self Directed Learning and Achievement in Information Technology for the Total Sample and Subsample Gender

\begin{tabular}{|c|c|c|c|c|}
\hline \multirow{2}{*}{ No. } & Variables Correlated & \multicolumn{3}{|c|}{ 'r' value } \\
\cline { 2 - 4 } & $\begin{array}{c}\text { Total Sample } \\
(\mathrm{N}=150)\end{array}$ & $\begin{array}{c}\text { Boys } \\
(\mathrm{N}=77)\end{array}$ & $\begin{array}{c}\text { Girls } \\
(\mathrm{N}=73)\end{array}$ \\
\hline 1 & $\begin{array}{c}\text { Self Directed Learning and Achievement in } \\
\text { Information Technology }\end{array}$ & $0.319^{* *}$ & $0.355^{* *}$ & $0.270^{* *}$ \\
\hline
\end{tabular}

"Significant at .01 level

Table 3. Comparison of Boys and Girls on Self Directed Learning and Achievement in Information Technology

\begin{tabular}{|c|c|c|c|c|c|}
\hline Variables & Gender & $\mathrm{N}$ & Mean & S.D & t-value \\
\hline \multirow{3}{*}{$\begin{array}{c}\text { Achievement in Information } \\
\text { Technology }\end{array}$} & Boys & 77 & 23.73 & 3.26 & \\
\hline & & & & & 1.19 \\
\hline & Girls & 73 & 24.44 & 3.71 & \\
\hline \multirow{3}{*}{$\begin{array}{l}\text { Self Directed } \\
\text { Learning }\end{array}$} & Boys & 77 & 130.25 & 5.77 & \\
\hline & & & & & 1.01 \\
\hline & Girls & 73 & 131.16 & 5.36 & \\
\hline
\end{tabular}




\section{Major Findings of the Study}

- There exists significant positive Correlation between Achievement in Information Technology and Self Directed Learning of Students at Secondary Level for the Total Sample and Subsample Gender

- There is no significant difference in Self Directed Learning of Students at Secondary Level based on Subsample Gender

- There is no significant difference on Achievement in Information Technology of Students at Secondary Level based on Gender.

\section{Educational Implications of the Study}

- The variable Self Directed Learning and Achievement in Information Technology are positively correlated. This implies that the Teaching and learning activities in IT classrooms should focus on the ways for enhancing the Self Directed Learning capacity of the students. The activities in the IT classrooms must be properly designed to enhance the Self Directed Learning of the students and also, the teachers should motivate the students to improve the Self Directed Learning capabilities, which gains momentum in the $21^{\text {st }}$ century classrooms especially in technology based classrooms

- The IT curriculum should be restructured for giving ample space for the learning activities that will cater to the needs of students and thereby promote Self Directed Learning among them.

- The result which shows no significant difference between Boys and Girls in Self Directed Learning and Achievement in Information Technology is a merit of the present Educational system. It is a good sign that Gender disparity does not exist in the Achievement level and level of Self Directed Learning. But the Teaching-learning process must be made more strengthened by developing creative and efficient ways of Teaching Methods and Techniques to reduce the disparity based on gender to the minimum level possible.

\section{Conclusions}

The concept of self-directed learning prevails in educational technology as a way to differentiate learning, change the role of learners and teacher in the classroom, alter the time/place of learning, and revolutionize traditional schooling. New developments in 21 st century education such as online learning opportunities, pedagogical shifts and availability of Internet on mobile devices have put additional expectations on learners to take more initiative in their own learning. Many, Fyfe, Lewis, \& Mitchell ${ }^{[6]}$ argues that teachers need to model learning strategies such as predicting, questioning, clarifying, and summarizing, so that students will develop the ability to use these strategies on their own. Teachers also need to allow individual learners to approach a task in different ways using different strategies. By giving ample opportunities for the enhancement of Self Directed Learning for the students, it also increases the Achievement in Information Technology of the students at Secondary Level.

\section{REFERENCES}

[1] Saxena, S. How Technology supports Self-Directed Learning. 2013. Available from:

http://edtechreview.in/news/824-how-technology-supports-sel f-directed-learning.

[2] Lounsbury, J. W., Levy, J. J., Park, S. H., Gibson, L. W., \& Smith, R. An investigation of the construct validity of the personality trait of self-directed learning. Learning and Individual Differences. 2009; 19(4): 411-18.

[3] Gibbons, M. The self - directed learning handbook: Challenging adolescent students to excel. San Francisco, CA: Jossey - Bass; 2002.

[4] Carlson, S. The Net generation goes to college: The Chronicle of Higher Education. 2005. Available from: www.cpcc.edu/ millennial/

[5] Knowles, M.S. The making of an adult educator. San Francisco: Jossey-Bass; 1989.

[6] Many, J.E., Fyfe, R., Lewis, G. \& Mitchell, E. Traversing the Topical Landscape: Exploring Students' Self-Directed Reading. Reading Research Quarterly. 1996; 31(1): 12-35. 